\title{
Common Types of Crime And Deviance Among University Students In Kenya. The Case Of Njoro Campus Of Egerton University
}

\author{
Hadija Matuli Murenga \\ Egerton University Njoro, Kenya. \\ Department of Peace, Security and Social Studies
}

\begin{abstract}
The study aimed at exploring the common types of crime and deviance among university students in Kenya, the case of Njoro Campus, Egerton University. A sample of 67 undergraduate students was drawn from eight (8) faculties at various levels of academics. The study found that theft and drug and alcohol abuse were the most common crimes while sexual immorality was the most common type of deviance action committed by students. The study concluded that opportunity crimes and deviance were the most rampant in Njoro Campus of Egerton University. Such crimes and deviance are facilitated by the presence of suitable targets, presence of motivated offenders and absence of capable guardians to guard against actions of crime and deviance. The study recommended that the problem of crime and deviance is real in the university and stern measures need to be taken by the university management to get the situation under control and reduce levels of crime and deviance for a more tolerable environment for all students. The study also recommended that thorough investigations should be done on cases of crime and deviance and those found guilty punished accordingly. The security department should work closely with Njoro Police Station especially on serious offences committed both inside and outside the university space such as external drug peddling. This is to serve a stern warning to any other students who may wish to commit such a crime.
\end{abstract}

Key words: Crime, Deviance, university student

\section{INTRODUCTION}

This study was motivated by the ever increasing crime and deviant rates among university students in Kenya. The researcher acknowledges the fact that manageable levels of crime and deviance in any institutions are acceptable but there is concern when levels constantly rise like is the case in most institutions of higher learning in Kenya.

The major question raised is; why is it now more than ever, most university students are being lured to criminal activities and deviant behaviors? Crime and deviance is making university students a pale shadow of what is expected of them. Levi obijiofor(2012), argues that universities in Nigeria might have lost the values for which they were established. He sees the reason for this as the ever increasing number of students getting involved in a bizarre sub culture of crime and deviance which is at odds with curriculum content of programs by the university. Obijiofor wonders why students are swelling up the ranks of criminal gangs to live unsustainable lifestyles that are based on sharp practices of illegalities.

Obijiofor (2012) likens life in Nigerian universities to living in a jungle. He argues that quality teaching and research cannot take place in an atmosphere in which the students feel that they have to disregard rules in order to achieve learning objectives in general. According to Obijiofor the drift to crime and deviance is because students cannot find honorable 
alternatives in tertiary education system. Thus, in the race for survival, many students break the codes of social conduct and ethical considerations. These scenarios provide a perfect ground for students to take part in crime and deviance.

Figures from several tertiary institutions paint a starting picture of the extent of crime and deviance in South Africa statics of criminal activities provided by the University of Zululand put it in a bad light. Since 2007 thirty-four (34) of its students have been convicted of a host of violent crimes including murder, rape, and possession of unlicensed firearms. Another 326 cases are before courts. The drive to crime and deviance among South African students include; lack of money to pay fees, to buy food and other expenses and general moral decay as greedy among some students which push them to crime and deviance to splash out fashionable clothing and trendy cellphones(Seals, 2011). If the incidences reported in both the mainstream as well as social media are anything to go by, there is need for concern on the rising levels of crime and deviance in Kenyan universities. Upon admission, the universities during orientation socialize new students on the desired behavior and informal and formal rules and regulations. However, the increasing number of students that face universities disciplinary committees calls for serious concerns. These students are usually suspended for long academic periods, expelled and on the extreme the expulsion may be accompanied by a jail term.

Kenyan universities seem to have become a source of consternation, dismay and utter horror for many parents and guardians. Parents and how afraid that they will be sending their children to go and die, get entangled to crime or simply wallow in the ignomy that the universities are now said to be a melting pot of fraud with students being sucked into national and international money laundering using their computer skills( the standard 2012).

Universities are characterized by riots in which students destroy property like was the case in university of Nairobi that lead to expulsion of over one hundred students; examination malpractices in almost all universities; drug and alcohol abuse; homicide from love triangles , as in the case of Moi university in Eldoret, to issues of moral decay leading to prostitution must all be understood( Murenga 2015).

\section{Statement of the Problem}

Despite setting clearly in the Egerton University Students' Handbook on the desirable behaviors and modes of conduct for students, some violate these rules and regulations. Crime statistics from the security department at Njoro Campus show an upward trend in the levels of crime and deviance. This is in the presence of dire consequences that students face for deviating from the institutions norms and involving themselves in crime and deviance. It is therefore on this backdrop that the study endeavored to explore the common types of crime and deviance among Egerton University in Njoro campus.

\section{Objective of the study}

The specific of this study was to explore the common types of crime and deviance among students of Egerton University, Njoro campus.

\section{METHODOLOGY}

The study was conducted in Njoro campus of Egerton University Kenyan. The study employed descriptive research design. This design entailed collection of data from the respondents so as to determine the current status of the population with respect to the variables under study. The study adopted choice of the of the study site was selected purposively. Stratified and simple random sampling was used to select the facilities and department for the study. The unit of analysis in this study was individual female or male students in the different academic 
levels selected for the study. The study sample was 80 but 67 returned the tools of data collection. The questionnaire was the main tool of data collection.

The study used descriptive analysis to harness and make sense out of the data collected. Simple statistics such as percentages were used to summarize and provide direction for conclusions.

\section{Characteristics of respondents}

\section{RESULTS}

The sample of this study consisted of 67 respondents who were degree students drawn from 8 faculties at different levels of academics. This is summarized in the Table 4.1

Table 4.1 : Academic level study of respondents

\begin{tabular}{|l|c|c|}
\hline Years of study & Frequency & Percentage \\
\hline First year & 19 & 28.36 \\
\hline Second year & 8 & 11.94 \\
\hline Third year & 14 & 20.9 \\
\hline Fourth year & 26 & 38.8 \\
\hline Total & $\mathbf{6 7}$ & $\mathbf{1 0 0}$ \\
\hline
\end{tabular}

Selection of respondents at the departmental level was judgmental and based on convenience. The judgmental process saw class representatives selected and in other faculties more students in their fourth year were selected in comparison to first, second and third year students. The fourth year students were perceived to have more information on crime and deviance as compared to other students. The class representatives were purposively selected because they interact and represent fellow students on a number of issues. They even sit in sensitive meetings with authorities, including disciplinary committees.

Table 4.2 Gender of Respondents

\begin{tabular}{|l|c|c|}
\hline Gender & Frequency & Percentage \\
\hline Male & 47 & 70.1 \\
\hline Female & 20 & 29.9 \\
\hline Total & $\mathbf{6 7}$ & $\mathbf{1 0 0}$ \\
\hline
\end{tabular}

There were more male students participating in the study than females as is shown in the Table 4.2 above. The male students seemed to be more than willing to participate than their female counterpart. The male students argued that they are more conversant with the issues of crime and deviance on campus than their female counterparts because of their activities on campus. Female students tend to spend a lot of their time indoors as compared to the males.

Table 4.3: Most common types of crimes experienced in Njoro campus

\begin{tabular}{|l|c|c|}
\hline Type of crime & Frequency & Percentage \\
\hline Theft & 45 & 67.2 \\
\hline Drug and alcohol abuse & 15 & 22.4 \\
\hline Vandalism & 5 & 7.5 \\
\hline Robbery & 2 & 2.9 \\
\hline Total & $\mathbf{6 7}$ & $\mathbf{1 0 0}$ \\
\hline
\end{tabular}

The findings in Table 4.3 above show that the most common type of crime among students in Njoro campus was theft (67.2\%), followed by drug and alcohol abuse $(22.4 \%)$ while robbery was the lowest at $2.9 \%$. Theft was rampant on campus due to the following reasons

- Presence of valuable items that attract thieves such as expensive electronics 
- Poor maintenance of property such as broken locks and windows combined with poor security strategies such as poor patrols made it easy to commit theft

- Financial strains due to high cost of living amidst limited pocket money as provided by parents/guardians

- Lack of contentment from some students who steal to sustain a certain type of lifestyle on campus

The study sought to establish the perpetrators of the above discussed types of crime by student on campus. The results are as presented in Table 4.4 below:

Table 4.4: Perpetrators of crime in Njoro Campus

\begin{tabular}{|l|c|c|}
\hline Perpetrators & Frequency & Percentage \\
\hline Both Male and female students & 40 & 59.7 \\
\hline Male students & 20 & 29.9 \\
\hline Students and outsiders & 5 & 7.5 \\
\hline Ex- students & 2 & 2.9 \\
\hline Total & $\mathbf{6 7}$ & $\mathbf{1 0 0}$ \\
\hline
\end{tabular}

From the findings in Table 4.4 above, a majority (59.7\%) of the respondents reported that both male and female students were equally responsible for the crimes in the university, while $29.9 \%$ felt that male students are the ones responsible for crime on campus. An interesting revelation also came up that some students steal together with outsider accomplice $7.5 \% 0$ as well as ex- students who live around the university (2.9\%). On the whole, this study found that both female and male students irrespective of their years of study ca be perpetrators of crime on campus.

The study also sought to establish the gender of the students likely to become victims of crime and deviance on campus. The results are reported in Table 4.5 below:

Table 4.5; Gender of likely victims of crime and deviance on campus

\begin{tabular}{|l|c|c|}
\hline Gender & Frequency & Percentage \\
\hline Male and Female & 7 & 10.44 \\
\hline Male & 15 & 22.4 \\
\hline Female & 35 & 52.24 \\
\hline Not sure & 10 & 14.92 \\
\hline Total & $\mathbf{6 7}$ & $\mathbf{1 0 0}$ \\
\hline
\end{tabular}

Findings in Table 4.5 above reveal that female students at 52.24 are the most likely to become victims of crime and deviance on campus. Male students followed at 22.4\%. Female students were the most likely to become victims of most crimes and deviant acts because they were seen as weak and unable to defend themselves thus becoming an easy target due to their feminine vulnerability (70\%). Some respondents also felt that the male criminals took advantage of female students' inferiority to men (30\%).

\section{Forms of Deviance in Njoro Campus}

This study found that the most common type of deviant behavior among students in Njoro campus were as shown in Table 4.6 below: 
Table 4.6: Common Types of Deviance by students in Njoro Campus

\begin{tabular}{|l|c|c|}
\hline Type of Deviance behaviour & Frequency & Percentage \\
\hline Sexual Immorality & 37 & 55.22 \\
\hline Indecent Dressing & 12 & 17.91 \\
\hline Out of control house parties & 10 & 14.93 \\
\hline Tribalism & 8 & 11.94 \\
\hline Total & $\mathbf{6 7}$ & $\mathbf{1 0 0}$ \\
\hline
\end{tabular}

Table 4.6 above shows that a majority (55.22\%) of the respondents mentioned various forms of sexual immorality as the most common type of deviant act on campus. These include: prostitution, fornication and irresponsible sex with different partners. Some respondents (17.91\%) reported that indecent dressing by female students was common in campus and it was a deviant act.

The study sought to find out if there will be an increase or decline in the levels of the various types of deviance on campus. The results are reported in Table 4.7 below:

Table 4.7: Whether the levels of different types of deviance are likely to fall or rise

\begin{tabular}{|l|c|c|}
\hline Prediction of levels of deviance & Frequency & Percentage \\
\hline Going to increase & 47 & 70.15 \\
\hline Going to decrease & 12 & 17.91 \\
\hline Not Sure & 8 & 11.94 \\
\hline Total & $\mathbf{6 7}$ & $\mathbf{1 0 0}$ \\
\hline
\end{tabular}

Table 4.7 above indicates that a majority (70.37\%) expect the levels of deviance on campus are going to rise. This is higher compared to the $17.91 \%$ respondents who reported that the levels of deviance will drop. The majority felt that this rise would occur due to the forms of deviance such as sexual offences and sexual immorality which are overlooked and assumed to be a normal characteristic of the youth, not only in Njoro campus of Egerton University but also other universities. As a result, very little and insufficient efforts are usually put in place by university management to curb such deviance acts. Though there are clear university rules and regulations with regard to students' conduct while on campus, such rules were not adhered to by students due to the laxity of enforcing the rules. The excess amount of freedom at the disposal of students made students adopt a carefree attitude about what others thought of them. This combined with negative peer pressure made students to engage in deviant acts such as sexual immorality and drug and alcohol abuse. Some respondents reported that the tough life on campus for some students forced them to adopt a survival mechanism which in most cases is deviant in nature. This included prostitution for female students, theft among others.

\section{DISCUSSION OF FINDINGS}

This study found that the most common types of crime were theft, drug and alcohol abuse, vandalism and robbery while the most common types of deviance were sexual immoralitysexual immorality, indecent dressing. Out of control house parties and tribalism. The finding that theft was the most common type of crime is in line with the finding by Faccidom (2016) that burglary with the intent to commit crime was most common form of crime in most university campuses.

The female students were the most likely to become victims of crime. This finding agrees with the finding by Wootten et. al (2016) who found that female university students in Britain were more likely to become victims of crime than the male students. This current study found that 
female students were more vulnerable than their male counterparts. However, both male and female students were found to be equally able to commit crime and deviance.

This current study also found that most crimes committed on campus are opportunity crimes. This finding agrees with the findings by Baxter and Sentinel (2016) which found that most of the crimes in the university are crimes of opportunity. This is further explained by the routine activities theory by Cohen and Felson (1979) who argued that for any crime to occur, the following three elements must be present: an accessible and suitable target; the absence of capable guardians that could intervene and the presence of a motivated offender. In this current study, theft was the most common crime on campus and the reasons why it was common can be argued to be sub-branches of the three elements that must be present for a crime to occur as follows: the presence of items that could be stolen such as mobile phones provide a suitable and valuable target, poorly maintained property such as broken windows, locks combined with poor security patrols by incompetent guards meant that there was an absence of guards to stop theft when a motivated offender (students who steal) found the target. Thus, the ever presence of these three elements in campus makes various forms of crime and deviance to occur. They get an opportunity to commit crime and get away with it.

Despite the relativity in crime and deviance, crimes and deviant acts committed in Egerton university, Njoro campus are almost similar to those committed in other institutions of higher learning in the world. This can be attributed to effects of a global village that is made true by advanced technology.

\section{CONCLUSION}

Opportunity crimes and deviant acts were found to be the most rampant in Njoro campus. These crimes and acts of deviance were facilitated by the presence of suitable targets, presence of motivated offenders and absence of capable guardians to guard against actions of crime and deviance. Both female and male students were likely to commit various types of crime and deviance. This is because they were likely to be equally predisposed to crime and deviance. Female students were likely than male to be victims in most crimes and deviance because of their perceived weakness by the male students

This study found that students in Njoro campus had too much freedom at their disposal which led to some of them engaging in crime and deviance. The study established that the university administration had failed to control the freedom of the students leading to a rise in the levels of crime and deviance. Most respondents felt that, if the university came up with ways of making students more responsible for the freedom at their disposal, it would be able to control the various types of crime and deviance in campus.

\section{RECOMMENDATIONS}

This study found that incidences of crime and deviance among university students in Njoro campus were high and on the increase. Most of the crimes and deviance acts committed were opportunistic in nature. This study established that the biggest problem in controlling crime and deviance in Njoro campus was laxity in enforcement of the rules and regulations governing the students conduct on campus. Tis study recommends that:

- There is need for increased awareness of the consequences of breaking such rules and regulations by students.

- Those found guilty for crime and deviance should not be treated with leniency or mercy.

- Investigations prior to disciplinary action should be thorough to seal any loopholes that wrongdoers would use to get away with the offences that they might have committed. 
- There is need for improved Security department that has to look into its staff especially security guards, some of whom get compromised by students and allow some vices to go on in campus.

- Security department should review and improve its working relationship with surrounding agencies of criminal justice especially Njoro police station so that there can be better control of crime and deviance in Njoro campus.

\section{References}

Atwoli, L; Mungala, P.A; Ndungu, M.N; Kinoti, C.K; and Ogot, E.M (2015). Pevalence of Substance use among College Students in Eldoret, Western Kenya. Retrieved from www.ncbi.nih.gov/pubmed/21356035. Accessed on $10 / 6 / 2017$

Baxter, S. and Sentinel, C.S. (20160. Stanford ranks no. 1 in State Crime per Student. UC Berkely no.2, UC Santa Cruz no.4. Retrieved from www. Santacruzsentinel.com/article/zz/.../1604196. Accessed on 12/5/2016

Faccidom, J. (2016). The common offences committed in the university campuses. Retrieved from www.rflawgroup.com/tg/defense-of-florida-college-students/Accessed on 10/5/2017

Felson (1979). Routine Activity Theory. Retrieved from https:/onlinelibrary.wiley.com.dol>pdf. Accessed on $10 / 4 / 2018$

Murenga, H.M. (2015). Lessons from First Degree Crimes of Passion. Daily Nation Newspaper of 27/March 2016

Obijiofor, L. (2012). Universities as nests of criminals. Retrieved from www.nigeriavillagesquare.com/leviobijiofor/universities. Accessed on 15/5/2017

Seals, J. 92011). College Freedom the good, the bad and the ugly. Retrieved from https://www.scholarship.com/.../college-freedom-the -good-the-ugly. Retrieved on 11/6/2016

Tara, P. P.(2008). College Students behaving badly. Retrieved from wellblogs.nytimes.com/2008/31/collegestudents-behaving-badly/. Accessed on 8/5/2016.

Wootten et.al. (2016). Crime Concentration and Hot spot Dynamics in Latin America. https://webimages.ladb.org>document. 